\title{
THE INFLUENCE OF METROPOLITAN AREAS ON REGIONAL DEVELOPMENT. RZESZÓW AS COMPARED TO OTHER METROPOLITAN AREAS IN EASTERN POLAND
}

\author{
ZBIGNIEW MAKIEŁA, AGNIESZKA SOBALA-GWOSDZ \\ The State School of Higher Vocational Education in Jarosław \\ Czarnieckiego 16, 37-500 Jarosław, Poland \\ e-mail:pwsz@pwszjar.edu.pl
}

\begin{abstract}
If it is to be argued that concentrating on providing support to largest urban centres is one of the main methods of stimulating the socio-economic development of Eastern Poland, it would seem necessary to first check, if since 1989, in the conditions of market economy, their so far observed development did indeed have an effect on their hinterland. Using the example of Rzeszów, the capital of Podkarpackie region, the authors delimit the strength, character and directions of impact of a capital of a semi-peripheral region. Basing their reasoning on the research of the range of the daily urban system, a zone of strongest influence and metropolitan effects of Rzeszów was delimited. Next, the dynamics of change in the level of life and the level of development of municipalities in the zone as compared to other areas of the Podkarapackie region were measured. Though as demonstrated by research results, within the area of strong spatial influence of Rzeszów positive spread effects dominate, metropolitan functions in the city's hinterland are weakly developed.
\end{abstract}

Key words: metropolisation, development, hinterland, competitiveness

\section{INTRODUCTION}

The thesis of the dominating role of metropolises in the socio-economic development of regions is unquestionable, as is the argument that civilisation development is increasingly focused on metropolitan areas. Regions without metropolises develop at a slower pace and become peripheral. The advantages of large urban centres are visible in many forms, among others as benefits of competitive advantages, localization, concentration and urbanization. The benefits of competitive advantages stem from the inequalities in the level of socio-economic development which are a characteristic feature of territorial units. The origins of such disproportions may be linked 
to geographic or historic factors but also to barriers in the flow of factors of production inputs. Due to them large or innovative firms may prefer certain areas and a concentration of modern production branches and highly skilled labour will follow. The location and concentration advantages resulting among others from the clustering in rather small areas of many global firms operating in the same or connected economic branches and entities with supra-regional functions are visible against this background (universities and other institutions of higher education, banks, corporations). The process of concentration of functions and capital in metropolises leads to interaction effects most often taking place in the field of communications and spatial influence. They include the circulation and exchange of information. Information sources are much richer in large cities, resulting in better access to means of communication, cooperating institutions and organisation and create the so called neighbourhood effect. External advantages of scale also include the creation of a specialized labour market in the region, the creation of conditions for cooperation with global entities, specialisation of banks and insurance companies, etc.

Urbanisation advantages result from the concentration of highly skilled population, representing an urban life style, and whose expectations lead to the concentration of higher rank functions. Metropolises are spaces where the changes in the socio-economic system are fastest and are the result of the civilisation development process in which immaterial values such as knowledge, high qualifications, entrepreneurial spirit, creativity and innovativeness are of decisive importance (Ładysz 2009). As the result of the increase in the openness of the economy towards foreign trade and free circulation of capital, development of new technologies and specialized infrastructure and consumption orientation of population metropolises are main beneficiaries of fast economic growth.

The briefly described process of developing advantages also leads to a gradual increase in the external effects of the metropolis, and results not only in the increased flow of foreign investments, specialists and managers but also in the establishment of diverse institutions and strengthening of the civil society and local democracy, development of inter and intra cultural cooperation and creation of metropolitan systems. It points out to the fact that metropolisation processes are of decisive importance with respect to the supremacy of metropolitan regions over surrounding areas.

Metropolisation may be understood as such development of urban space which leads to expansion, export and emulating solutions formulated in metropolises and in order to develop searches twin examples (Czepczyński 2008) ${ }^{1}$. Metropolisation process may thus be regarded as having features of elite development which means that non-metropolitan areas are excluded as they are not 'invited to cooperate' (Domański 2008). It may not however automatically mean that non-metropolitan areas are

\footnotetext{
1 'I notice two aspects present in the contemporary understanding of metropolises, jointly impacting on understanding the term, and stemming from the ancient Greek concept of the "Mother" city: creation of urban models copied by other cities or areas, which may be described as "the export of the idea of metropolis" and the impact of metropolises on other cities through higher rank and innovative functions. Such impact may be measured looking at the share in the global (or continental) circulation and transfer of goods, information and ideas' (Czepczyński 2008).
} 
marginalized and have no possibilities of speeding up their development (Malisiewicz 2007). It has to be acknowledged that a faster pace of development of metropolitan regions leads to the effect of increasing distance between metropolises and other towns and cities. As diffusion of functions is a characteristic feature of metropolisation processes regions where metropolises are located are prone to develop faster than other regions. This also means that regions where the process of metropolitan growth is not externally supported will never catch up in their development with regions where the process of metropolisation is already present, and the economic and civilisational distance between them will continue to grow.

While analysing the development of metropolises and metropolitan areas some researchers put forward a thesis that metropolises develop autonomously and display stronger internal links and links between metropolises while the surrounding hinterland of those cities is neglected or excluded. The process of weakening, or even severing the economic links of metropolises with their regional hinterland, which becomes functionally unnecessary to the metropolises takes place (Gorzelak and Jałowiecki 2000; Jałowiecki 2007). The growing independency of metropolises from their regional surrounding takes place especially in the knowledge economy (Gorzelak and Smętkowski 2005). It leads to marginalization of surrounding regions while the disparities between the metropolis as the centre and peripheries are become more and more pronounced (Smętkowski 2007). The Warsaw agglomeration may be given as an example of such development within Poland. The case of Krakow is different, as according to Domański et al. (2009), Krakow is strongly integrated with its hinterland and at the same time is an urban centre from which development impulses and innovations radiate on the entire region.

Delimiting the strength, character and direction of impact of a metropolitan region on its hinterland is indispensable from the regional development theory point of view (Gorzelak and Smętkowski 2005; Makieła 2007, Markowski and Marszał 2007). The analysis of the impact of the dominating urban centre is of special importance in the context of semi-peripheral or peripheral regions; Eastern Poland being universally regarded as such. If the main method of supporting such areas is to be the concentration of means on the development of regional capitals and strengthening of their competitiveness (Kozak 2009), it would seem necessary to analyse how their so far observed, generally speaking endogenous development, has impacted on their surroundings.

As follows, the aim of the article's authors is delimiting the strength and directions of impact of Rzeszów as a potential metropolitan centre on the economic development of its hinterland. In other words putting forward a hypothesis that Rzeszow is the main growth pole in the Podkarpackie region, it would be necessary to check if positive spread effects of its development are visible in the region or conversely if at the current stage of development backwash effects dominate. Implementing this aim necessitates firstly delimiting the range of spatial impact of the analysed urban centre, assessing the strength of this impact and then analysing the changes in 
the level of socio-economic development of territorial units located within its sphere of influence.

The remaining part of the article is divided into three sections. The first section presents the unique features of Podkarpackie region as one of the problem regions of Eastern Poland. Next, results of research on the scope and strength of impact of Rzeszów on the region are presented as well as the characteristic features of development of its hinterland in the past twenty years. Finally, conclusions and policy implications stemming from the analysis are presented in the last section of the article.

\section{PODKARPACKIE REGION AGAINST THE BACKGROUND OF MAIN DEVELOPMENT PROBLEMS OF EASTERN POLAND}

The macro-region of Eastern Poland according to the delimitation undertaken for the purpose of the programme Strategy for socio-economic development of Eastern Poland until 2020 (2008) includes five regions (Lubelskie, Podkarpackie, Podlaskie, Świętokrzyskie and Warmińsko-mazurskie). Jointly, the above regions represent $32 \%$ of Poland's surface, inhabited by close to $22 \%$ of the country's population who produce about $16 \%$ of the GDP. Its lowest level of economic development in comparison to other EU regions is the common feature of this macro-region (without taking into account Romania and Bulgaria). The distance in development in comparison to more wealthy regions is maintained being the result of overlapping and compounding of many development barriers. As suggested by A. Kukliński (2008) in Eastern Poland one encounters one of the "Gordian knots" or deadlocks of regional development in Europe. Such problems include the macro-region's demographic features, settlement network, economy, geographic location (i.e. its peripherality and the issues of accessibility), infrastructure and, last but not least, human and social capital.

The demographic barriers are connected to the processes of outflow of residents from the macro-region and the process of population aging. In 1999-2007 the macro-region's population declined by 133.4 thousand persons, with highest declines observed in the Lubelskie (52.7 thousand) and Świętokorzyskie regions (38.3). Eastern Poland is visibly different from other parts of the country with respect to the high negative balance of migration. In 2006 net migration balance in Poland amounted to ca. $1 \%$, in Eastern Poland to ca. $-2.5 \%$, and within it in Lubelskie region to almost $3.0 \%$, Podlaskie region to $2.5 \%$ and Podkarpackie region to $2 \%$. Age groups of 5-14 and 20-24 dominate in the process of migration which means that it is young families who leave the region. According to the results of research conducted among young residents of Eastern Poland who decided to migrate out of the region, a significant share of migrants are persons with higher education. It is thus a very negative process of backwashing human capital, as exactly those persons who completed their higher education in the institutions of Eastern Poland leave 
the region. The process of population aging is spatially differentiated, its dynamics and directions being influenced both by natural increases and migrations. It is most visible in the Lubelskie region (Strategy for socio-economic... 2008, p. 21-22). Among the regions within Eastern Poland solely in the Podkarpackie region a relatively high natural increase may be observed, distinguishing it from the neighbouring Lubelskie and Świętkorzyskie regions.

Lower population density is also a characteristic feature of Eastern Poland, with population density ranging from 118 persons per $\mathrm{km}^{2}$ in Podkarpackie region to 56 persons per $\mathrm{km}^{2}$ in Podlaskie region (in comparison to the national average of 122 persons per $\mathrm{km}^{2}$ ). The situation in the rural areas of Podlaskie region is even worse (26 persons per $\mathrm{km}^{2}$ in comparison to the national average of 50 persons per $\mathrm{km}^{2}$ ). In Podkarpackie region a relatively high index of population density in rural areas (74 persons per $\mathrm{km}^{2}$ ) is however accompanied by a low level of urbanisation $(40.7 \%)$, lowest in Poland. Such low level of urbanisation in the region is strongly influenced by historical factors ${ }^{2}$. Neither the industrialisation processes initiated in the interwar period with the construction of Central Industrial Region (COP-Centralny Okreg Przemystowy) nor the industrialisation processes which followed the World War II did not satisfactorily change the urbanisation level in the region, instead of significantly increasing the level of urbanisation, leading to the mass phenomenon of workers from rural areas commuting to work in urban centres. Generally speaking in Podkarpackie region a more densely populated western and central part and a less densely populated south-eastern part may be distinguished. Lower population density of the latter is among others the result of the deportations of the Ukrainian and Lemko population after 1945.

Overall, there are 205 towns and cities within the entire area of Eastern Poland, among which smaller urban settlements with population up to 5,000 persons dominate. A small number of both medium size and larger urban settlements is a characteristic feature of the regions in Eastern Poland. In the macro-region there are only 6 cities with over 100,000 inhabitants. With the exception of Elblag, all of them fulfil the regional capital function, including three potential metropolitan centres (Lublin - with a population of 358.5 thousand, Białystok-294.8 and Rzeszów-176.0). Apart from Rzeszów, in Podkarpackie region only two other urban centres with population over 50,000 may be found, as well as five towns with a population ranging from 20-50,000 inhabitants (Table 1). A specific problem regarding the settlement network of the region is the clustering/cumulating in its eastern part of towns and cities which are still dependent on a single industrial function, while in the eastern part of the region there are urban centres with weakly specialised functions.

\footnotetext{
2 In the 1930s Eastern Poland was a weakly urbanised macro-region with a share of urban population below $30 \%$. Since that time the pace of urbanisation processes was changeable. In 2006 the level of urbanisation was as follows: Warmińsko-mazurskie region-59.5\%, Podlaskie 59.2\%, Lubelskie 46.1\%, Świętokrzyskie $45.2 \%$ and Podkarpackie $40.2 \%$ in comparison to much higher national average of $62.2 \%$.
} 
Table 1. Population of urban settlements in Eastern Poland in 2008

\begin{tabular}{|l|c|c|c|c|c|c|c|}
\hline \multirow{2}{*}{ Region } & \multicolumn{7}{|c|}{ Number of urban settlements } \\
\cline { 3 - 8 } & \multirow{2}{*}{ Total } & \multicolumn{7}{|c|}{ Population size } \\
\cline { 3 - 8 } & $0-5,000$ & $\begin{array}{c}5,000- \\
10,000\end{array}$ & $\begin{array}{c}10,000- \\
20,000\end{array}$ & $\begin{array}{c}20,000- \\
50,000\end{array}$ & $\begin{array}{c}50,000- \\
100,000\end{array}$ & $\begin{array}{c}\text { More than } \\
100,000\end{array}$ \\
\hline Lubelskie & 41 & 31 & 3 & 1 & 4 & 1 & 1 \\
\hline Podkarpackie & 47 & 17 & 14 & 7 & 5 & 2 & 1 \\
\hline Podlaskie & 37 & 18 & 6 & 5 & 5 & 2 & 1 \\
\hline Świętokrzyskie & 31 & 14 & 6 & 5 & 3 & 2 & 1 \\
\hline $\begin{array}{l}\text { Warmińsko- } \\
\text { mazurskie }\end{array}$ & 49 & 17 & 8 & 13 & 8 & 1 & 2 \\
\hline Total & 205 & 97 & 37 & 31 & 25 & 8 & 6 \\
\hline
\end{tabular}

Source: Own elaboration based on GUS data.

Potential metropolitan centres of Eastern Poland are smallest cities included by the Union of Polish Metropolises among metropolises and metropolitan areas. An important problem of those agglomerations, which slows down the process of metropolisation, is their small population potential combined with the lack of modern technological and economic infrastructure systems, infrastructure and institutional structures attracting foreign capital to locate their branches, congress and exhibition centres and modern sports infrastructure allowing for the promotion of the cities and helping to shape and enhance the economic links with the global economy. Although institutions of higher education are an important advantage of the macro-region, taking into account their low research and development potential, they still require significant support and deep organisational changes.

Synthetic index of economic strength and potential such as GDP per inhabitant places Eastern Poland in the last position within the country. Lubelskie region is the weakest economically region with GDP per inhabitant slightly above $68 \%$ of the national average. The regions of Eastern Poland are also characterised by lowest indices of entrepreneurial activity within the country. Decidedly weakest entrepreneurial activity (measured by the number of firms registered in the REGON system per capita) is a feature of Podkarpackie region. Furthermore, the regions of Eastern Poland are agricultural areas with a disadvantageous agrarian structure - a high share of population employed in agriculture and a low share of agricultural production intended for the market. The decidedly worst situation may be observed in Podkarpackie region with as much as $7.4 \%$ of all persons employed in agriculture in Poland working in this region, while the value of agricultural products sold by the producers in the region (e.g. value and volume of cereals sold) is lowest in the country. The dispersed and fragmented land ownership structure (the average surface of farming land is only 2.59 ha!), combined with a large number of persons working in agriculture and low degree of market orientation is one of the region's main problems. 
Economic analyses point to the fact that, as the result of marginalisation of eastern regions of Poland in the investment processes after World War II, industry in the region is in need of deep modernisation. Presently, in all regions of Eastern Poland, the gross value added in industrial production per one employee is lower than the national average, showing further tendencies to decline. Only in the Podkarpackie region the share of industrial production in GDP creation is higher than the share of agriculture (Strategy for socio-economic... 2008, p. 29-30). In addition, Podkarpackie region benefits from relatively high innovative capabilities of its industry 3 . The clustering in the region of the high and medium technologies in aviation industry and partly automotive industry makes it unique among the other regions in Eastern Poland. These industries as well as other traditional branches (such as for example the glass industry in the southern part of the region and the wicker industry in the vicinity of Rudnik nad Sanem) thanks to which the workers in the region possess unique skills are one of the main though not enough appreciated resources of the region.

A relatively weak innovativeness of firms in Eastern Poland combined with the peripheral location of the macro-region with respect to main markets and buyers makes them less competitive in the national market. Due to its weak endowment with technological and economic infrastructure Eastern Poland is included among areas of low investment attractiveness. In comparison to other Polish regions, the regions located in the Eastern parts of the country are areas receiving a much lower average volume of foreign investment per capita. In the case of Podkarpackie region this stems mainly from the small size and number of investments in the service sector (cf. Sobala-Gwosdz et al. 2006). The underdevelopment of higher rank services is one of the main development barriers of Podkarpackie region. There are few economic entities providing services in branches connected to modern technology and know-how, firms which could take advantage of the existing scientific and technological potential. This is one of the main reasons for out migration of well qualified and more talented employees from the region.

For peripheral regions such as the regions of Eastern Poland regional policy on the state level is of high importance. Its expression should be supporting such regions at the expense of better developed areas. In the 1990s Special Economic Zones (SEZ) served this purpose. Following the changes in approach to preferentially treated areas however, SEZ became an element of support given to companies and not to regions, which lead to the eastern regions losing one of the main competitive advantages in attracting larger foreign investors (Gwosdz et al. 2008).

In regions of Eastern Poland the sector of non market services is relatively well developed. Non market services are a dominating sector here in terms of GDP creation, however thanks to a low GDP value per capita their importance is not big. Higher level education in the region may serve as an example. In absolute numbers institutions of higher education serve a greatest number of students in Lubelskie

\footnotetext{
${ }^{3}$ In 2006 the region ranked in the fourth position in Poland with respect to spending on R\&D in industry
} 
region (above 107,000 students-7th position in Poland), while significantly less students attend higher education institutions in Podlaskie region (53,000 students, 14th rank in the country). Unfortunately, the relatively high number of students does not go in line with the international activities of universities such as participation in scientific programmes financed by the EU. Only few institutions of higher education in Eastern Poland are well known or enjoy international esteem, while the share of population with higher education in the total population (scholarisation index) is much lower than the national average. It is lowest in the Podkarpackie region amounting to about $25 \%$ in comparison to the national average of $37 \%$.

Eastern Poland is included among the EU regions with lowest transport accessibility. The major problem of the region is its low internal coherence in terms of transport networks and lack of modern links with most important national and continental transport routes and corridors. The process of integration and transport compatibility is a challenge for the spatial policy of the country. It is hard to agree with the concept of functional links within the country on the basis of the hexagon model recently proposed in the Expert project: the concept of spatial planning in the country until 2033. In this model the regions of Eastern Poland are visibly condemned to peripheralisation and for many years the division of the country between a strong economic centre and peripheries will be underlined and perpetuated. Lack of modern infrastructure systems, most of all transport infrastructure will enhance and perpetuate the peripheral character of eastern regions and will also significantly limit the process of penetration/diffusion of functions, multiplier effects and other advantages being the result of the diffusion process of metropolis on the surrounding (Makieła 2005). It would seem right to agree with the argument put forward by B. Domański $(2008)^{4}$, that diffusion barriers should be overcome, since endogenous development leads to retaining multiplier effects generated by large firms and that unquestionably exerts a positive influence on the economy of the municipalities outside metropolitan areas. One of the more important factors making the process of diffusion of functions easier is the construction of active links of modern infrastructure system and creating conditions of shaping partner settlement networks with dominating growth poles-metropolises. Taking that into account, the information and scientific expertise questioning the need of S19 motorway, which is to link the regional capitals in Eastern Poland with the country's southern border arise concern. The construction of S19 would strengthen the communication alongside the Baltic-Black Sea axis and would be a chance to increase economic activities in the belt of municipalities nearby the border. One of the key and still unsolved problems is the necessity of fulfilling the promise of action on the via Baltica communication route.

\footnotetext{
${ }^{4}$ A much more effective policy may consist of actions aimed towards overcoming barriers to endogenous development of peripheral regions based on local small and medium enterprises. First of all, one may argue that the success in regional and local development in the areas in question will be to a greater extent than in better developed regions possible without strong links with international economy, based on local, regional or national markets. Local activities are its basis, and a special role may be played by leaders and institutions, who are able to "push" the local structures towards changing the conditions of development created in the past" (Domański 2008, p. 7).
} 
Of strategic importance for Eastern regions is the interaction: eastern borderregion-entrepreneurship. The opinions enhancing the view that the eastern border is a barrier to international cooperation should be actively counteracted. Although in the introduction to the Strategy of socio-economic development of Poland until 2020 one may read a statement: "The widespread view that the Polish eastern and northeastern border is a barrier to transfer of ideas and cooperation is not based on sound evidence", the evaluation of residents, entrepreneurs and tourists remains different. The weak openness of the border not only to tourism traffic but also to the flow of goods, information and scientific or cultural contacts seems to be the confirmation of these opinions. One of the reasons is the concentration of border traffic in few border crossing points. The nod of border traffic Medyka-Korczowa-Przemyśl concentrates almost $30 \%$ of all eastern border traffic. If traffic on border crossings in Dorohusk, Hrebenne and Krościenko was included, in total the above mentioned border crossing points represent over 53\% of the entire border traffic across the Polish eastern border. Infrastructure backwardness of the eastern border is also confirmed by the fact that one border crossing point with Ukraine serves as much as $45 \mathrm{~km}$ of the Polish-Ukrainian border, above $32 \mathrm{~km}$ of the Polish-Belarussian border and almost $40 \mathrm{~km}$ of the Polish-Russian border. In comparison alongside the western border of Poland (prior to the accession of Poland to the EU) on average there was a border crossing point for every $12 \mathrm{~km}$ of the border. As mentioned earlier, the activities of eastern regions are linked to the trans-border cooperation. Its implementation does not only require the construction of a larger number of border crossing points, modern transport and institutional infrastructure but also creating an atmosphere conducive towards such cooperation.

\section{RANGE AND STRENGTH OF INFLUENCE OF RZESZÓW ${ }^{5}$}

No doubts are raised with respect to the inclusion of Lublin, Białystok and Rzeszów as small 5th rank metropolises in the concept of Metropolises and metropolitan areas in Poland, taking into consideration factors such as the rank of the cities, their position in the settlement hierarchy in Poland and other criteria including the functions they provide in accordance with the approaches of other EU countries and the US. As follows, according to this concept there are three types of metropolises in Poland: large, medium and small. Similarly, T. Markowski (2005) distinguishes among global, supranational and national (regional) metropolises. Small metropolitan centres

\footnotetext{
5 The range and scope of influence of higher and medium rank functions located in Rzeszów was researched by establishing the zone of daily commuting (daily urban system), zone of influence as academic/higher education centre and economic power centre. The main source base covered data on the gravity/ travel patterns of secondary school students, number and time of public transport connections, permanent place of residence of university students studying in Rzeszów, size of foreign direct investments (FDI) and the actual place/sites of conducting activity by medium and large size firms registered in Rzeszów. A detailed methodology of processing the above mentioned data, obtained within the State Committee for Scientific Research (KBN) project "Growth centres and stagnation areas in Podkarpackie region” may be found in publications of A. Sobala-Gwosdz $(2005,2007)$ and A. Sobala-Gwosdz et al. (2006).
} 
such as Lublin, Białystok and Rzeszów fulfil all basic, additional and supplementary functions that a large or medium size metropolis provides. They differ however in the scale and intensity of functions, population size, surface as well as the economic, social and technological potential.

Without including the city itself, daily commuting range of Rzeszów includes between 200,000 to 210,000 persons, depending on the method of measurement. The range of spatial influence of Rzeszów is modified by sub-regional centres in Podkarpackie region such as Krosno, Jarosław, Stalowa Wola or Mielec, and by Tarnów in the neighbouring Małopolska region, the latter being only slightly smaller than Rzeszów from demographic point of view. The range and strength of Rzeszów' direct influence is more pronounced with respect to less developed areas within the Podkarpackie region i.e. in the north and in the east corners of the region, whereas its influence in the south and in the west is limited by the strong urban centres mainly Krosno and Tarnów. As many as 277,000 persons live within a 30 minute travel time equidistant to Rzeszów, 575,000 persons within a 60 minute equidistant.

The scope of influence of higher rank institutions located in Rzeszów is much larger than the zone of daily commuting to the city. The leadership of Rzeszów in the Podkarpackie region with respect to fulfilling the higher education functions is

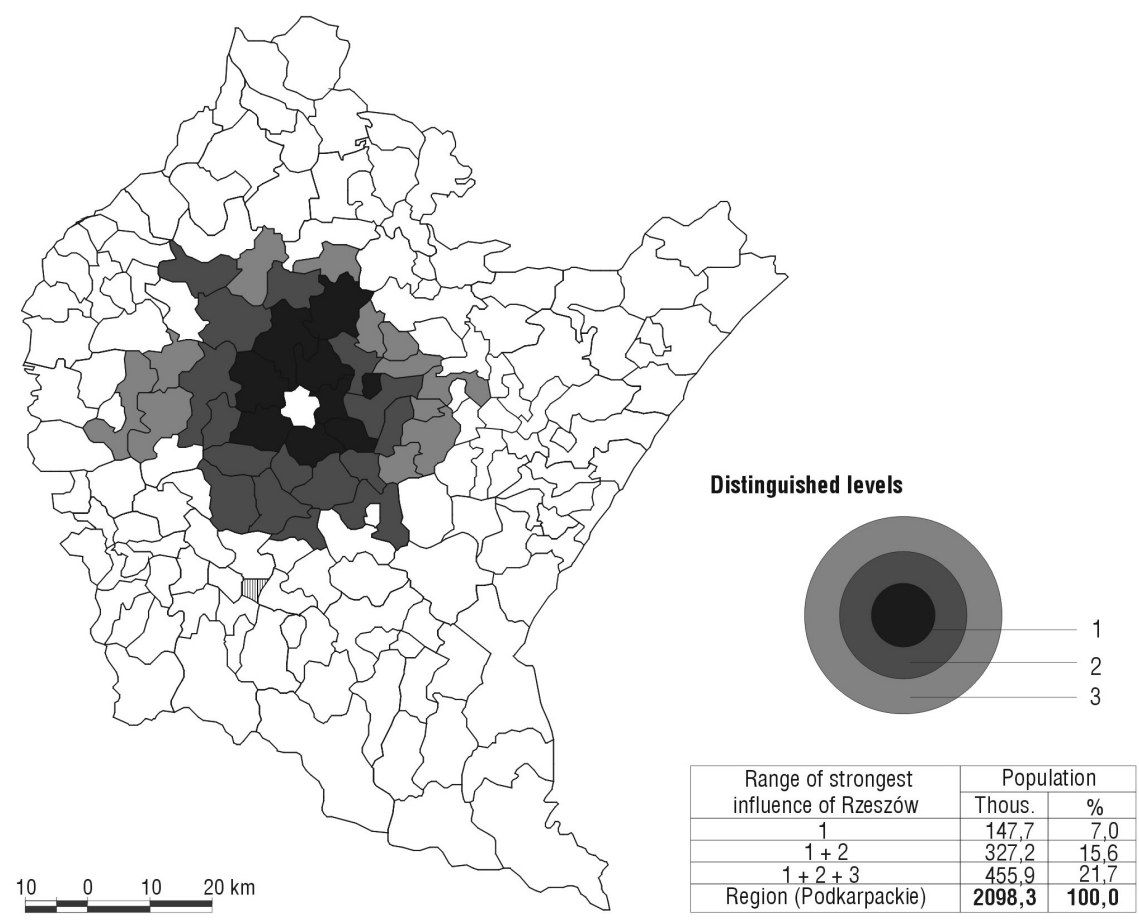

Figure 1. The range of spatial influence of Rzeszów and its potential metropolitan area Source: Sobala-Gwosdz, A. (2007). 
unquestioned. An influence of this urban centre on the areas in neighbouring regions especially Lubelskie and Małopolskie may also be observed. Gravitation from other regions of Poland towards Rzeszów is negligible. Looking at the range and strength of influence of the Rzeszów academic centre a similar relation may be observed as in the case of its daily urban system. The scope and strength of influence of Rzeszów is more visible in the less developed Lubelskie region. In Małopolska region because of the competition of the main supra-regional centre of Southern Poland-Krakowthe influence of Rzeszów is limited to the eastern part of the region.

On the other hand, the spatial range of control functions of Rzeszów is mainly limited to the area of Podkarpackie region (cf. Sobala-Gwosdz 2007). Although out of 2,000 largest enterprises in Poland, 27 have headquarters in Rzeszów (Lista 2000, 2004), taking into account both the number of headquarters and the income generated by largest firms, the capital of Podkarpackie region ranks lower than Lublin and Kielce.

Based on the results of the three methods presented a synthetic map of zones of strongest influence and impact of Rzeszów as a large urban centre was delimited (Figure 1), showing the potential future metropolitan area of Rzeszów (cf. SobalaGwosdz 2007). It comprises of 38 municipalities with a population of 456,000 i.e. $22 \%$ of the population of Podkarpackie region. Including the population of Rzeszów, it comprises an area inhabited by 616,000 persons i.e. $29 \%$ of the region's population.

\section{INFLUENCE OF RZESZÓW ON ITS HINTERLAND}

One of the main challenges in establishing the scope of impact of growth poles is delimiting both the range and type of spread effects and backwash effects. While researching the spread effects of Rzeszów the information on the dynamics of change in the level of life and the level of development of municipalities in Podkarpackie region since 1990 was used (cf. Sobala-Gwosdz 2005). The assumption was that if municipalities located within the sphere of influence of the city would display a faster pace of socio-economic development than the other municipalities in the region, the hypothesis on the positive influence of that centre on its hinterland would be confirmed.

In the case of Rzeszów the spatial extent of spread effects takes on a classic form, i.e. the development pole is surrounded by a belt of municipalities with highest observed positive effects and then a belt of weaker effects. This is visible both in synthetic indexes and individual data e.g. on unemployment (cf. Figure 2). Strong positive effects were observed in the case of 8 municipalities neighbouring the city, in total being a home to 119,000 residents and covering the surface of $763 \mathrm{~km}^{2}$. In the next 5 municipalities this influence is noticeable but weaker. One may thus conclude that the extent of influence of an urban centre with a population of 160,000 located in a peripheral region reaches a population size at least equal to the size of 
the city's population. It is worth remarking that the sphere of strongly visible positive effects overlaps with the sphere of dominating gravitation towards the city (cf. Sobala-Gwosdz 2005). Weaker accessibility of Rzeszów from the south-eastern direction is reflected in the lower level of life and level of economic development of the areas in that part of the region.
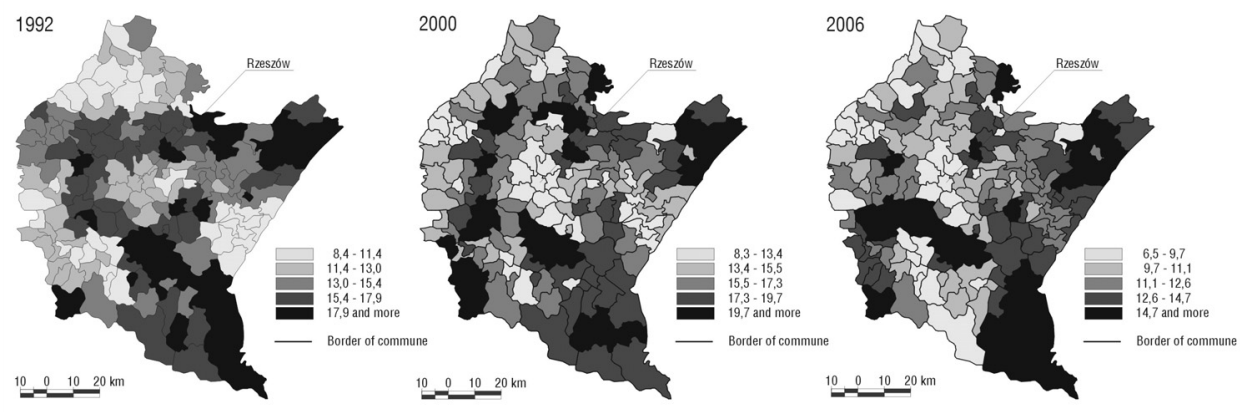

Figure 2. Unemployment in Podkarpackie region

Source: Own elaboration based on GUS data.

Metropolitan functions within a metropolitan area should be provided by the entire area and not only by the urban centre which creates it, As follows, such functions should be located in different parts of the metropolitan area and not only within the administrative limits of its main city. In the case of Rzeszów there are so far few such functions in its surroundings as it would be difficult to regard as such the location of few large surface retail establishments in Krasne municipality or few medium size industrial greenfield investments in Chmielnik and Krasne municipalities. Of regional importance are institutions of higher education in Tyczyn and Ropczyce, while the only supra-regional function is the Jasionka airport in the vicinity of which the formation of an edge zone of economic activity is observed.

\section{CONCLUSIONS}

Taking into account the historic factors, geographical location and present day socio-economic situation of regions in Eastern Poland, without a doubt, one may argue that it is necessary to undertake important decisions with respect to the implementation of development strategies for the entire area. Such strategies should aim at slowing down the process of increasing spatial and socio-economic differentiation between Eastern Poland and other parts of the country. The views and concepts speaking of the dilution of the concept of the country's metropolisation should be abandoned and an approach supported that in the context of Poland, especially Eastern Poland, medium size metropolises do have a role to play. Taking into account the so far observed economic, social and infrastructure potential, geographic location and some of the mentioned external development opportunities, as well as 
the possibilities of the EU Structural Funds support, one may argue that there exist all premises that through effective use of the existing potentials (strengths), better usage of the opportunities offered by endogenous features and external opportunities, Lublin, Białystok and Rzeszów do have development chances and in the relatively near future may become medium size metropolises.

In the light of the research conducted, it has been established that within the sphere of strong influence of Rzeszów positive spread effects dominate, although the metropolitan functions in the city's hinterland are weakly developed. Low rank and low indices of the share of population of metropolises and metropolitan areas of Eastern Poland in comparison to other regions in the country suggest that the process of their development requires strong external support. The aims and directions of such supporting activities should be included in the regional development strategy. There should also exist a political will and power of their implementation. Lack of visible actions aimed at strengthening the settlement network in Eastern Poland and the creation of strong growth poles (future metropolises) within it arises concern and leads to the danger of further depreciation of those regions for many years to come.

\section{REFERENCES}

Czepczyński, M. (2008), Strategie samorządów polskich metropolii wobec wyzwań Strategii Lizbońskiej, in: Marszał T.(ed.), Rola polskich aglomeracji wobec wyzwań Strategii Lizbońskiej, Studia KPZK PAN, 120, 125-134.

Domański, B. (2008), Rozwój polskich metropolii a regiony peryferyjne. Bezpowrotna separacja czy współzależność rozwoju, in: Marszał T. (ed.), Rola polskich aglomeracji wobec wyzwań Strategii Lizbońskiej, Studia KPZK PAN, 120, 135-143.

Domański, B., Guzik, R., Gwosdz, K. and Micek, G. (2009), The transformation of Matopolska: experiences and prospects for the twenty-first century, in: Jakubowska P., Kukliński A., Żuber P. (eds.), The future of regions in the perspective of global change, Ministry of Regional Development, Warszawa, 4/2, 95-133.

Gorzelak, G. and Jałowiecki, B. (2000), Konkurencyjność regionów, Studia regionalne i lokalne, 1, 7-24.

Gorzelak, G. and Smętkowski, M. (2005), Metropolia i jej region w gospodarce informacyjnej, Scholar, Warszawa.

Gwosdz, K., Jarczewski, W., Huculak, M. and Wiedermann, K. (2008), Polish special economic zones: idea versus practice, Environment and Planning C: Government and Policy, 26, 824-840.

Jałowiecki, B. (2007), Metropolie jako bieguny rozwoju, in: Gorzelak G. (ed.), Polska regionalna i lokalna w świetle badań EUROREG-u, Scholar, Warszawa, 143-162.

Kozak, M.W. (2009), Propozycje ekspertów. in: Identyfikacja i delimitacja obszarów problemowych $i$ strategicznej interwencji $w$ Polsce, Wnioski z analiz, Ministerstwo Rozwoju Regionalnego, 110-113. 
Kukliński, A. (2008), Gordian knots and alexandrian solutions. The perspectives of the XXI century, in: Jakubowska P., Kukliński A., Żuber P. (eds.), The Future of regions in the perspective of global change, Ministry of Regional Development, Warszawa, 3, 1, 134-155.

Lista 2000. Polskie przedsiębiorstwa, 2004, Rzeczpospolita, 12.10.2004, special addition.

Ładysz, I. (2009), Konkurencyjność obszarów metropolitalnych w Polsce, na przykładzie wrocławskiego obszaru metropolitalnego, Cedetu.pl, Rubinum, 19-23.

Makieła, Z. (2005), Funkcje infrastruktury techniczno-ekonomicznej w strukturze obszarów metropolitalnych, in: Makieła Z. and Marszał T. (eds.), Infrastruktura techniczno-ekonomiczna w obszarach metropolitalnych, Biuletyn KPZK PAN, 222, 7-19.

Makieła, Z. (2007), Procesy metropolizacji, obszary metropolitarne, in: Makieła Z. and Fedan R. (eds.), Procesy metropolizacji w regionie podkarpackim RzeszówLwów, Biuletyn KPZK PAN, 230, 53-62.

Malisiewicz, E. (2007), Małe metropolie sita napędowa rozwoju regionu na przykładzie miasta Rzeszowa, in: Makieła Z. and Fedan R. (eds.), Procesy metropolizacji w regionie podkarpackim Rzeszów-Lwów, Biuletyn KPZK PAN, 230, 141-150.

Markowski, T. (2005), Zarządzanie obszarem metropolitalnym, in: Bald K. and Markowski T. (eds.), Obszar Metropolitalny Łodzi, Wyzwania i problemy, Biuletyn KPZK PAN, 215, 8-24.

Markowski, T. and Marszał, T. (2007), Metropolitan areas of Poland-challenges and policy recommendations, in: Marszał T. and Zmitrowicz W. (eds.), Metropolises and metropolitan areas-structures, functions and role, Studia Regionalia, 20, 9-22.

Smętkowski, M. (2007), Nowe relacje metropolia—region $w$ gospodarce informacyjnej na przykladzie Warszawy i Mazowsza, in: Gorzelak G. (ed.), Polska regionalna i lokalna w świetle badań EUROREG- $u$, Scholar, Warszawa, 163-187.

Sobala-Gwosdz, A. (2005), Ośrodki wzrostu i obszary stagnacji w województwie podkarpackim, IGiGP UJ, Kraków.

Sobala-Gwosdz, A. (2007), Siła i zasięg przestrzennego oddziaływania Rzeszowa jako głównego ośrodka regionalnego Polski Południowo-Wschodniej, in: Makieła Z. and Fedan R. (eds.), Procesy metropolizacji w regionie podkarpackim RzeszówLwów, Biuletyn KPZK PAN, 230, 151-164.

Sobala-Gwosdz, A., Działek, J., Gwosdz, K., Huculak, M., Jarczewski W. and Micek, G. (2006), Inwestycje zagraniczne w województwie podkarpackim do 2005 roku, Lista największych inwestycji zagranicznych w województwie podkarpackim, Rzeszowska Agencja Rozwoju Regionalnego, Rzeszów.

Strategy for socio-economic development of Eastern Poland until 2020, 2008, Ministry of Regional Development, Warszawa. 